\title{
Preservation and Significant Values of Cultural Heritage of the Tomb Complex of King Hadat Banggae in Ondongan, Majene Regency, West Sulawesi
}

\author{
Khadijah Thahir Muda ${ }^{*}$, Yusriana ${ }^{2}$ Nur Ihsan D. ${ }^{2}$ \\ ${ }^{1,2,3}$ Archaeology Department Faculty of Cultural Sciences Hasanuddin University \\ *Corresponding author. Email: khadijah@unhas.ac.id
}

\begin{abstract}
At the site of the Tomb Complex of the Kings and Hadat Banggae in Ondongan, Majene Regency. It is the location of choice for archaeological research, the location is the basis for consideration because the site has relics of ancient tombs since the beginning of the development of Islam in Majene Regency. These ancient Islamic tombs are facing a high threat of damage due to construction and natural weathering. Therefore, this study also aims to be able to identify these cultural relics before experiencing extinction related to preservation. The important value attached to this cultural heritage is useful for discussion so that the existence of this ancient Islamic tomb complex site is a concern for more serious care. This research shows the historical, scientific, religious and cultural importance of the site. Both by the government and the people of Majene Regency in particular and other people in general.
\end{abstract}

Keywords: Graves, Preservation, Cultural Heritage, Important Values

\section{INTRODUCTION}

\subsection{Background}

The cultural diversity that exists in the archipelago as cultural heritage is countless, from 17,000 islands and tribes, as well as races. This diversity also influences the findings of archaeological sites found as well as movable and immovable objects as archaeological resources. Including the diversity of culture in the form of non-physical (intangible) and physical culture (tangible). Mundardjito said that cultural heritage strengthens national values, it should always be renewed without reducing its meaning. To be used optimally in terms of strengthening national values. According to him, this is also not only the task of archaeologists but all disciplines are expected to play an active role, giving meaning to the current historical heritage [1].

The existence of cultural heritage objects in the archipelago has different conditions seen from various causes that can trigger damage and weathering of archaeological remains as cultural heritage objects. This is understandable because the situation and condition of each cultural heritage are also not the same, the cause is from within the cultural heritage object itself such as age, location, material, and from outside the cultural heritage object such as the environment, climate and so on. Due to the different conditions of these cultural objects, several preventive actions were taken to rescue them. This preventive action is carried out based on the level of damage, which will be assessed based on the value of importance based on the applicable rules according to the Cultural Conservation Law No. 11 of 2010.

Based on the Law on Cultural Conservation Number 11 of 2010 legally stipulates to protect and preserve cultural heritage which states that: Cultural heritage is the nation's cultural wealth as a form of thought and behaviour of human life which is important for understanding and developing history, science, and culture in the life of society, nation and state so that it needs to be preserved and managed appropriately through efforts to protect, develop and utilize it in the context of advancing national culture for the greatest prosperity of the people.

As a cultural heritage or archaeological remains, the total number of tombs contained in the Tomb Complex of the Kings and Hadat Banggae is 480 tombs made from, among others; lava stone, earth stone, and some tombstones made of wood. The tombs have decorative motifs such as floral and geometric carvings, Arabic calligraphy, and swastika symbols. 
The site of the Tomb Complex of the Kings of Hadat Banggae has been listed as a Cultural Conservation site. Archaeological conservation measures to control and inhibit the process of damage to objects have been carried out. Damage to the tomb, both to the tomb as a whole and some wooden tombstones, is influenced by both biotic and abiotic environments. Weather, air temperature, rainfall spur the damage process. Damage analysis is done by observing the objects and problems encountered in the field. The environment plays an important role in the conservation of cultural heritage or archaeological remains because the environment where the site is located can make the site as archaeological remains last longer, it can also be due to environmental conditions that are not suitable or supportive of the material from archaeological remains. For the latter condition, the most frequent damage is the rapid process, the coastal environment with high levels of salination or salt. Salt easily triggers corrosion or rust, salt.

Many things that can trigger damage and weathering are not only environmental conditions but also the quality of the material that supports it to survive or vice versa the quality of the material can make the condition of archaeological remains fragile. Various conditions experienced by the tombs of Raja Hadat Banggae, attract attention to re-evaluate after archaeological conservation is carried out because through this study the identification of damage and weathering at the site of the Tomb of the Kings of Hadat Banggae can be known so that conservation actions can be carried out appropriately. Given the importance of this site as important data, especially for the culture of Majene Regency and as part of the nation's culture.

\subsection{Description of the Tomb Complex of the Kings of Hadat Banggae}

The Tomb Complex of the Kings of Hadat Banggae is believed to be a cemetery for kings and members of the Hadat council of the kingdom of Banggae. The Hadat Banggae Council is thought to have existed during the reign of Daeng Tamilanto (Mara'dia Banggae II or the 2nd king). The figure of Daeng Tamilanto was written in history as a figure who developed the kingdom's territory by cooperating with traditional leaders (tomakaka) around him.

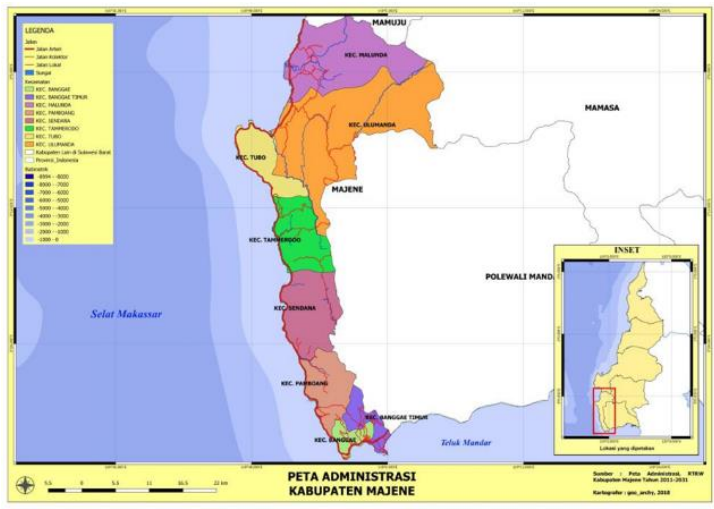

Gbr. 1. Peta Kabupaten Majene (sumber:

https://www.google.com/url?sa=i\&url=https $\% 3 \mathrm{~A} \%$ 2F\%2Farchysig.wordpress.com\%2F2019\%2F05\% 2F14\%2Fkabupaten-majene. Downloaded 6 Juni 2021

Administratively, the location of the research location, the Tomb Complex of the Kings of Hadat Banggae is included in the Pangali-ali neighborhood, Pangali-Ali Village, Banggae District, Majene Regency, West Sulawesi Province. To facilitate access to the site, you can refer to the Majene Regent's Office, from the east by going through a settlement a distance of $\pm 850 \mathrm{~m}$ (See Figure 1).

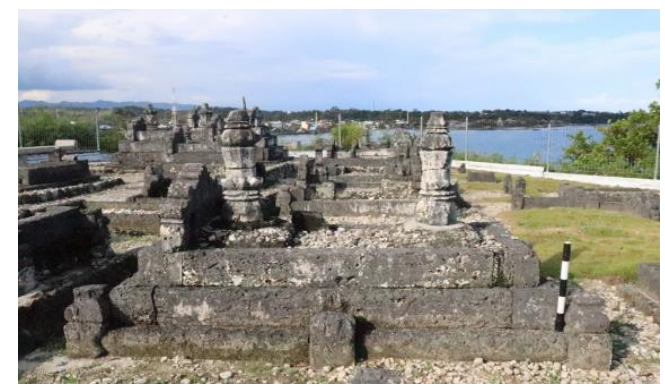

Figure 1: Tomb of the Kings of Hadat Banggae of Majene Regency

(Erwin U Saraka, 2021)

This site is located astronomically, at the coordinates of $3^{\circ} 32^{\prime} 31.6^{\prime \prime}$ South Latitude and $118^{\circ} 57^{\prime} 44.7^{\prime \prime}$ East Longitude and is located at an altitude of $46 \mathrm{~m}$ above sea level and faces directly towards Majene Bay. The area of this complex is about $10,589 \mathrm{~m} 2$. The location of this site is quite open in the north of the plantation area, in the west with public cemeteries and residential areas, in the south and east by the coast of Majene Bay.

In 1999 this raj-raja tomb complex was designated as a site with inventory number 151 this is based on the Decree of the Minister of Education and Culture Juwono Sudarsono no.240/M/1999 on 
October 4, 1999. Since 1981 by Abdul Muthalib has researched this site followed by Darmawan Mas'ud et al in 1994.

Based on data from the Department of Tourism and Culture of Majene Regency, the restoration has been carried out twice, the first in 1987-1988 and the second in 1988-1990. Then, in 2014 zoning was carried out on this tomb site by a team from the SulSelRa Cultural Heritage Preservation Center. Archaeological conservation activities were also carried out in 2014, archaeological conservation this time was more focused on tombs and gravestones made of rock.

\section{RESEARCH METHOD}

This research applies a qualitative approach and studies of legislation related to cultural heritage. Implementation in the field, collecting library and field data. Collection of library data in the form of research reports and articles related to the history of Mandar, management of cultural resources and preservation of cultural heritage.

This study used archaeological research methods consisting of three stages, namely the stages of data collection, analysis and interpretation of data. In the data collection stage, library data collection and field surveys and interviews were carried out. At the analysis stage, identification and classification of the type of damage and weathering of the tomb is carried out, then laboratory analysis is carried out to identify the type of microorganism attached to the tomb so that it can reveal the chemical weathering that occurred in the tomb.

\subsection{Library Data Collection}

The collection of library data is carried out by searching various literature, collecting data from two sources, namely archaeological data as primary data and historical data in the form of historical writings and lontara' chronicles, especially those directly related to field data or the theories and methods that will be used.

\subsection{Field Survey}

The archaeological data collection is carried out using archaeological survey techniques, namely direct observations in the field to record archaeological data. The archaeological survey conducted is a systematic survey to collect field data with activities in the form of inventory, measurement, depiction, aerial mapping, and description.

\subsection{Interview}

Interviews are an attempt to collect oral data from people who know about the evaluation to get information from the community about the environment, on various forms of jirat, tombstones, decorations and layouts of tombs.

\subsection{Analysis}

Data analysis or data processing regarding damage and weathering that occurred at the site of the Tomb Complex of the Kings of Hadat Banggae in Ondongan, Majene Regency. The first step in the classification of site data is to categorize the types of damage and weathering of tombs based on the level of damage. The next step is to identify the level of damage and weathering of data based on the results of data processing, analogies, comparisons. The results of the analysis can explain the causes and anticipation of rescue as cultural heritage objects that need to be saved.

\section{DISCUSSION}

\subsection{Preservation of Cultural Heritage}

Discussing the preservation of cultural heritage means that it is closely related to the use of cultural heritage because it is in the management of cultural heritage. Preservation means taking advantage of cultural heritage as something that is managed, to remain sustainable but beneficial to all levels of society. A cultural heritage that is managed within the framework of the work of conservationists is a sustainable activity, which is carried out systematically and responsibly because it has the basis of the Cultural Conservation Law No. 11 of 2010 in terms of managing cultural heritage. The results are expected to be useful for all people [5].

In essence, the preservation of cultural heritage, especially for historic buildings, can be defined as an effort to maintain and protect a historical heritage in the form of artifacts, buildings, cities and other historical areas. This is done by utilizing it following the old function or implementing a new function to finance its continued existence [2].

When cultural heritage management activities are carried out in the context of conservation, this activity must have careful planning, not only paying attention to objects of cultural heritage but all things related to the sustainability of these objects and are believed to be measurably sustainable. Studies conducted archaeologically, namely that cultural heritage cannot be separated from the environment and culture in general. Furthermore, preservation is an effort for culture both in the form of ideas, actions/behaviours, and 
material culture that is always in a cultural system that is still valid [6].

Important values for cultural resources will be beneficial if managed properly. Because this is part of conservation activities, which are expected to be beneficial to all levels of society, the insights and ideas of conservation must be well known by the people who own them, so that the process of conservation activities is supported by the community as cultural owners [4].

Empowering the community in the effort to preserve cultural heritage is an effort to increase the dignity of the people who are in the close environment of cultural heritage objects. This means increasing the ability of the community in terms of efforts to preserve cultural heritage objects. In the framework of that thought, efforts to empower the community must first begin by creating an atmosphere or climate that allows the potential of the community to develop. Furthermore, these efforts must be followed by strengthening the potential and power possessed by the community. In this context, more positive steps are needed, apart from just creating a climate and atmosphere [7]. The existence of the site of the Ancient Tomb Complex of the Hadat Banggae Kings, which is in the vicinity of the Majene City settlement, provides benefits that can be seen from the fairly high visits to this ancient tomb complex.

Conservation in this case is not passive, but dynamic. The dynamic nature that can be seen from visits to this ancient tomb complex every year continues to grow, with a variety of different purposes when they visit the site. The supervision of the preservation results that have been carried out on these ancient tombs has been carried out routinely and under control by the local government in this case the Majene Regency Culture Service and BPCB SULSELRA. This is a non-negotiable rule in terms of controlled conservation activities, an effort to maintain the values contained in the cultural heritage so that they are sustainable. It is hoped that cultural heritage preservation activities can synergize with development activities so that when activities are carried out they remain integrated and coordinated with the government for the ideal mental and physical development of the community [7].

\subsection{Important Value}

In the laws and regulations concerning Cultural Conservation in force in Indonesia, important values are the determining factors for a material cultural heritage to be designated as a Cultural Conservation. In addition, the content of important values is also the basis for determining the ranking of Cultural Conservation, as regulated in Article 41, Law no. 11 of 2010 concerning Cultural
Conservation. Therefore, the study of the important values of material cultural heritage is the main thing that is carried out in the process of determining it as a Cultural Conservation.

The rules regarding significant values in the Law of the Republic of Indonesia No. 11 of 2011 concerning Cultural Conservation, contained in Article 1 paragraph 1. In that article it is stated; Cultural Conservation is material cultural heritage in the form of Cultural Conservation Objects, Cultural Conservation Buildings, Cultural Conservation Structures, Cultural Conservation Sites, and Cultural Conservation Areas on land and/or in water that needs to be preserved because they have important values for history, science, education, religion, and/or culture through a process of determination.

The next article also mentions the significant values of cultural heritage including important values for history, science, education, religion, and culture. Then reinforced in the article in Chapter. III, regarding the criteria for cultural heritage, only this significant value is termed with a special meaning which also includes a special meaning for history, science, education, religion, and culture. In the explanation, it is stated that the special meaning, in this case, includes a special meaning for the community and special meaning for the nation. The special meaning for the community is having an important meaning for certain cultural communities, while what is meant by "special meaning for the nation" is having an important value for the state and people of Indonesia which becomes a unifying symbol, pride of national identity, or which is an extraordinary event on a national scale or the world.

\section{a. Historical Value}

The historical importance of the Ancient Tomb of the Kings of Hadat Banggae is from the history associated with Majene Regency, the majority tribe in this Regency is the Mandar Tribe.

The Kingdom of Banggae is one of the kingdoms that are members of the confederation of Mandar Pitu Ba'bana Binanga or commonly called the seven river mouths which were declared in Tammajarra in 1580 AD. The seven kingdoms were Balanipa, Sendana, Banggae, Pamboang, Tappalang, Mamuju, and Binuang Akbar, R dan Wijaya [2]. Speaking of the early history of the Banggae kingdom, before it grew and developed into a kingdom, it was inhabited by seven community groups, each of which had a government area that lived on top of the hills. The seven community groups are the Salogang community group, the Poralle community group, the Totoli community group, the Lambe Allu 
community group, the Mawasa community group, the Lambe' Susu community group, and the Naung Indu community group. The chief of this tribe came to be known as Tomakaka Poralle. Besides Tomakaka Poralle, there are other tomakakas who lead their respective groups who live around Banggae such as Tomakaka Pullajonga, Tomakaka Sallogang, Tomakaka Totoli, Tomakaka Pepottoang.

The presence of the Tomb Site of the Kings of Hadat Banggae is a witness to the greatness of the kingdom of Hadat Banggae at that time.

\section{b. Science Value}

The Tomb Complex of the Tomb of the Kings of Hadat Banggae has an important scientific value because it can be an object of research in developing science. From an architectural point of view, the Tomb of the Kings of Hadat Banggae has a distinctive design in the form of various tomb forms, both in terms of manufacture or architecture, ornaments attached to the tomb, have characteristics that are quite different from ancient tombs that are contemporaneous and are located in other places.

As a cultural heritage, the Tomb of the Kings of Hadat Banggae can be an object of historical study. The existence of the site of the Tomb of the Kings of Hadat Banggae in the middle of Ko Majene is considered one of the icons of the City of Majene.

The architectural style and design technology of the Tomb of the Kings of Hadat Banggae can be the object of archaeological study, especially in revealing the development, influence, and philosophical meaning behind the architecture of the Tomb of the Kings of Hadat Banggae.

From an anthropological perspective, the Tomb of the Kings of Hadat Banggae can be a learning medium, especially regarding the concept of the unification of various ethnic groups that existed in Majene at that time.

Referring to the description above, the Tomb of the Kings of Hadat Banggae is considered to meet the criteria of having special meaning for science, because it has the potential to be analyzed further to answer problems in the scientific field. The potential of the Tomb of the Kings of Hadat Banggae can be utilized to answer problems in the fields of forensic science (archaeology, history, anthropology, and sociology) and engineering sciences (architecture and civil).

\section{c. Education Value}

The Tomb of the Kings of Hadat Banggae can be a medium of learning, especially in the art of designing buildings. The application of technology to tombstones (jirat) to connect stones to form the desired tomb, with stone peg technology, and arrange tombstones. In addition, the ornaments found on tombs and tombs show quite a variety of decorative motifs, flower tendrils, geometrics, swastikas.

In general, in Islamic ancient tombs in South Sulawesi, the influence of Hinduism in South Sulawesi is very thin and limited. If you look closely, you will see more prehistoric traditions such as tombstones in the form of human statues, menhirs, palus, images of humans, horses and the sun, geometric. Some of the decorative motifs on the tomb are patterned with flora and fauna (Tjandrasasmita, et al 1983).

\section{e. Cultural Values}

When the importance of culture is discussed to see how far the ancient Tomb Site of the kings of Hadat Banggae is related to culture, ethnicity related to the Mandar Tribe will be included.

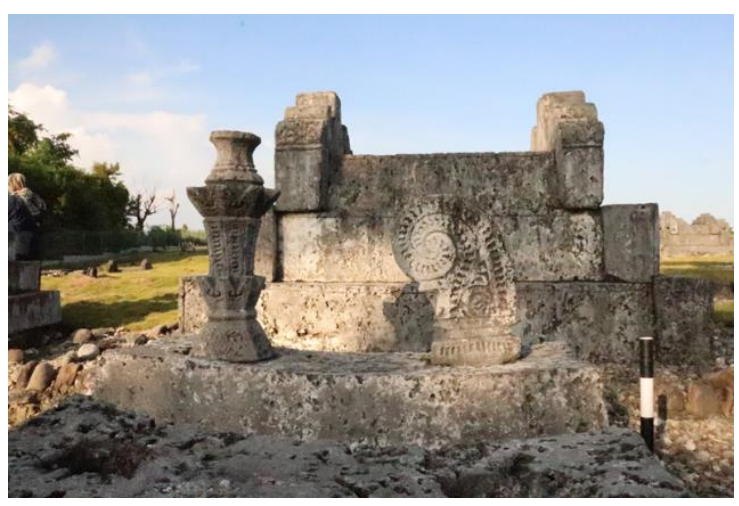

Figure 3: Hulu Keris Tombstone at the Tomb Complex of the Kings of Hadat Banggae (Erwin U.Saraka: 2021)

The ethnic values that exist at the site that can be shown can be seen in the shape of the tombstone on the tomb, the shape of the head of the keris is always present in several tomb complexes in West Sulawesi, such as the Tambulese Tomb Complex, Syech Abdul Manan Salabosse Tomb Complex, in West Sulawesi. Majene. The tombs of kings, nobles, religious figures provide traces through tombs that have distinctive tombstones, upstream kris so that they can be used as important archaeological data [3. By displaying the ornaments on this tomb, it is hoped that aesthetic values, ethics and noble values from the cultural results of our ancestors, especially in South Sulawesi, which show the characteristics of the 
local cultural layers during the development of Islam.

\section{CONCLUSION}

Cultural heritage in the form of the ancient tomb complex site of the Kings of Hadat Banggae, has received attention from both the government and the community. This is proven through preservation which begins with research on the existence of the site. Attention has been carried out several times in gradual restoration from 19871988 and 1988-1990. This ancient tomb complex has been used as a tourist destination by the Majene Regency Culture Service. Enthusiastic people visit this tomb for tomb pilgrimages, tours because, in addition to the beautiful scenery in this complex, the gardens and cleanliness are maintained by the caretakers who are stationed at this site.

Empowering the community in conservation efforts means involving them in these activities, making them mentally feel ownership and responsibility for the site. This utilization will be illustrated by the enthusiasm of the community to come to visit, creating an atmosphere or climate that allows the potential and insight of the community to develop.

At the time the restoration was carried out on this ancient tomb site, studies relating to the important values attached to the ancient tomb site had been carried out first, the results study resulted that this site was deemed necessary to be preserved, as a cultural heritage. To be used following Law NO 11 of 2010 on Cultural Conservation, Article 88 (1) Utilization of the found location that has been designated as a Cultural Conservation Site must pay attention to the function of space and its protection. (2) The Government and/or Regional Government may stop the utilization or cancel the permit for the utilization of the Cultural Conservation if the owner and/or those in control are proven to have damaged or caused the Cultural Conservation to be damaged. (3) Cultural Conservation which is no longer utilized must be returned to its original state before being utilized. (4) The cost of returning it to its original condition shall be borne by those who utilize the Cultural Conservation. Article 89 Utilization by means of multiplication of Cultural Conservation Objects.

\section{REFERENCES}

[1] Anonim. 2020. Warisan Budaya Harus Mampu memperkuat Nilai Kebangsaan. Media Indonesia. Rabu, 25 November 2020. 18.15

Wib.

https://mediaindonesia.com/humaniora/36392 2/warisan-budaya-harus-mampu-perkuatnilai-kebangsaan
[2] Akbar, R dan Wijaya,I.K, 2008. Manajemen Aset: Upaya Pelestarian Bangunan Bersejarah di Kota Bandung. Jurnal Perencanaan Wilayah dan Kota. Vol19/No1. 1 April 2008. Hal 13-33.

[3] Sakka, La.2014. Arkeologi Makam Syech Abdul Mannan di Salabose. Jurnal Pusaka, Vol. 2, No. 1, 2014. Hal 93-108

[4] Susanto, N. N. 2007. Nilai Penting Sumberdaya Arkeologi Bagi Daerah. Naditira Widya, 1(2), 244-254. https://doi.org/10.24832/nw.v1i1.348

[5] Tanudirjo, Daud Aris. "Pengelolaan Sumberdaya Arkeologi:Suatu Pengantar". Makalah untuk Pelatihan Pengelolaan Sumberdaya Arkeologi, di Trowulan, Mojokerto, 27 Agustus - 1 September 2004

[6] Mulyadi, Yadi. Museum Komunitas Alternatif Pelestarian Cagar Budaya Berbasis Masyarakat. Dalam Jurnal Museografi Vol. VI, No. 10 - Desember 2012

[7] Wibowo, Agus Budi. 2014. Strategi Pelestarian Benda/Situs Cagar Budaya Berbasis Masyarakat Kasus Pelestarian Benda/Situs Cagar Budaya Gampong Pande Kecamatan Kutaraja Banda Aceh Provinsi Aceh. Jurnal Konservasi Cagar Budaya Borobudur, Volume 8, Nomor 1, Juni 2014, Hal 58-71 